\title{
PENGARUH LATAR BELAKANG PENDIDIKAN ORANG TUA TERHADAP POLA ASUH ANAK PADA MASYARAKAT LIUKANG KALMAS KABUPATEN PANGKEP
}

\author{
Risfaisal $^{1}$, Lukman Ismail ${ }^{2}$ \\ ${ }^{1}$ Pendidikan Sosiologi, Universitas Muhammadiyah Makassar \\ Email: risfaisal@unismuh.ac.id. \\ 2Pendidikan Sosiologi, Universitas Muhammadiyah Makassar \\ Email: lukmanismail@unismuh.ac.id.
}

\begin{abstract}
This study examines the Effect of Background on the Education of Parents on the Parenting Style of the Pangkep Regency Liukang Kalmas Community. The main problem in this study is whether the level of education of parents is very influential on parenting and provides a pattern of awareness for parents to have a sense of responsibility and obligation to realize their children's needs. The purpose of this study was to analyze the influence of the level of education of parents on parenting in the community. This type of research is quantitative which aims to understand the social reality of the influence of parents' educational background on parenting in the community. Information is determined by purposive sampling, based on the characteristics of the informants that have been determined are parents who have low, middle and high education with 138 informants. Data collection techniques are observation, questionnaire, and documentation. The technique of analyzing data through various stages, namely data obtained from observations through questionnaires while the data validity technique uses triangulation of sources, techniques and time. The results of this study will be expected to provide a source of information to the surrounding community, government, and academics to see whether there is a significant influence related to parents' educational background to parenting in the Liukang Kalmas District, Pangkep Regency. Sustainability in this study contributes to knowledge that is meaningful for the development of education, especially in sociology, as a reference for teaching materials about learning social dynamics and parental behavior in caring for children in the family environment.
\end{abstract}

Keywords: Parent's Education Level, Child Parenting.

\begin{abstract}
Abstrak. Penelitian ini mengkaji tentang Pengaruh Latar Belakang Pendidikan Orang Tua Terhadap pola asuh Anak Pada Masyarakat Liukang Kalmas Kabupaten Pangkep. Masalah utama dalam penelitian ini adalah apakah tingkat pendidikan orang tua sangat berpengaruh terhadap pola asuh anak dan memberikan pola kesadaran bagi para orang tua agar memiliki rasa tanggung jawab dan kewajiban untuk mewujudkan kebutuhan anaknya. Tujuan penelitian ini adalah untuk menganalisis pengaruh tingkat pendidikan orang tua terhadap pola asuh anak pada masyarakat.Jenis penelitian ini adalah kuantitatif yang bertujuan untuk memahami realitas sosial terhadap pengaruh latar belakang pendidikan orang tua terhadap pola asuh anak pada masyarakat.Informan ditentukan secara purposive sampling, berdasarkan karakteristik informan yang telah ditetapkan yaitu orang tua yang berpendidikan rendah, menengah dan tinggi dengan jumlah 138 informan. Teknik pengumpulan data yaitu observasi, angket, dan dokumentasi. Teknik analisis data melalui berbagai tahapan yaitu data yang diperoleh dari observasi melalui angket sedangkan teknik keabsahan data menggunakan triangulasi sumber, teknik dan waktu. Hasil penelitian ini nantinya akan diharapkan memberikan sumber informasi kepada masyarakat sekitar, pemerintah, maupun akademisi untuk melihat apakah ada pengaruh secara signifkan terkait latar belakang pendidikan orang tua terhadap pola asuh anak di Kecamatan Liukang Kalmas, Kabupaten Pangkep. Keberlanjutan dalam penelitian ini memberikan sumbangan pengetahuan yang berarti bagi pengembangan pendidikan khususnya pada ilmu sosiologi.
\end{abstract}

Kata Kunci:Tingkat Pendidikan Orang Tua, Pola Asuh Anak. 


\section{PENDAHULUAN}

Pendidikan mempunyai peranan yang sangat menentukan bagi perkembangan dan kualitas diri individu, terutama dalam menentukan kemajuan pembangunan suatu bangsa dan negara. Tingkat kemajuan suatu bangsa tergantung kepada cara bangsa tersebut mengenali, menghargai dan memanfaatkan sumber daya manusia yang berkaitan erat dengan kualitas pendidikan yang diberikan kepada calon penerus dan pelaksana pembangunan. Lembaga pendidikan merupakan lembaga yang bertanggung jawab dan berkompetensi penuh atas proses pendidikan. Lembaga pendidikan wajib menyediakan berbagai fasilitas dan memenuhi kebutuhan peserta didiknya dalam upaya mencapai tujuan pendidikan. Keluarga adalah merupakan lingkungan pendidikan pertama bagi anak. Di lingkungan keluarga pertama-tama anak mendapat pengaruh, karena itu keluarga merupakan lembaga pendidikan tertinggi yang bersifat informal dan kodrat. Pada keluarga inilah anak mendapat asuhan dari orang tua menuju ke arah perkembangannya.

Keluarga adalah wadah utama dan agen pertama untuk memberikan sosialisasi kultur di setiap lapisan masyarakat. Keluarga juga sebagai media pertama yang memancarkan kultur kepada anak-anak sebab keluarga adalah dunia yang pertama kali menyentuh kegidupan anak-anak, keluarga merupakan dunia inspirasi bagi anak-anak. Anggota keluarga termasuk anak kecil mendapatkan pelajaran berbagai hal yang ada dalam keluarga, tanpa disadari bahwa apa yang terjadi dalam keluarga memberikan pengaruh sangat besar bagi kehidupan mereka. Demikianlah cara anak itu mereaksi terhadap lingkungannya. Ayah dan ibu dalam konteks kehidupan keluarga yang ideal, merupakan sosok yang paling dekat dengan anak. Ayah dan ibu merupakan pengambil peran utama sebagai orang tua untuk mengasuh anakanaknya. Terutama kedekatan anak terhadap ibu, karena ibunya yang mendukung, melahirkan dan menyusui sehingga secara psikologis mempunyai ikatan yang lebih dalam.

Di dalam sebuah keluarga, seorang anak pertama kali diajarkan pada pendidikan. Dari pendidikan dalam keluarga tersebut anak mendapatkan pengalaman, kebiasaan, keterampilan berbagai sikap dan bermacam-macam ilmu pengetahuan.Di samping itu keluarga merupakan lembaga pendidikan yang membekali anak dengan berbagai pengalaman sosial dan nilai moral. Lingkungan keluarga merupakan faktor pendukung terpenting bagi perkembangan kecerdasan anak. Dalam lingkungan keluarga anak menghabiskan waktu dalam masa perkembangan. Pengaruh lingkungan rumah ini berkaitan pula dengan masalah 
ekonomi keluarga. Dengan ekonomi keluarga yang memadai seseorang lebih berkesempatan mendapatkan fasilitas belajar yang lebih baik. Mulai dari alat tulis hingga pemilihan sekolah dan sebaliknya dengan sosial ekonomi yang kurang memadai seseorang juga kurang mendapatkan fasilitas belajar yang baik dan nutrisi yang baik pula.

Sehubungan dengan tingkat pendidikan orang tua akan memberikan pengaruh terhadap pola berpikir dan orientasi pendidikan yang diberikan kepada anaknya. Semakin tinggi pendidikan yang dimiliki oleh orang tua maka akan semakin memperluas dan melengkapi pola berpikirnya dalam mendidik anaknya. Kondisi yang berupa latar belakang pendidikan orang tua merupakan satu hal yang pasti ditemui dalam pengasuhan anak. Demikian pula terjadi di Liukang Kalmas, Kabupaten Pangkep, dimana tingkat pendidikan orang tua sebagian besar merupakan lulusan sekolah dasar dan sekolah lanjutan pertama, bahkan banyak yang tidak sampai tamat dalam mengikuti pendidikan formal.

Berdasarkan kondisi latar belakang pendidikan orang tua yang sedemikian, menyebabkan pola berfikir orang tua di Liukang Kalmas Kabupaten Pangkap masih cenderung tradisional dan kolot. Orientasi berfikir orang tua di Liukang Kalmas Kabupaten Pangkep mengenai jumlah anak dalam keluarga masih menganut falsafah Jawa kuno bahwa banyak anak banyak rezeki. Untuk masa dahulu memang ada baiknya, karena dengan basis pertanian dan kepemilikan lahan yang luas, semakin banyak anak berarti semakin banyak tenaga kerja yang dapat membantu dalam pengolahan lahan. Namun pola berfikir seperti itu, jika diterapkan untuk saat sekarang ini, sangat tidak cocok mengingat saat ini tidak semua orang tua memiliki lahan dan orientasi penghidupan sudah beralih dari agraris ke arah industri.

\section{TINJAUAN PUSTAKA}

\section{a. Teori Tabularasa (John Locke dan Francis Bacon)}

Teori tabularasa ini mengatakan bahwa anak yang baru dilahirkan itu dapat diumpamakan sebagai kertas putih yang belum ditulisi ( a sheet of white paper avoid of all characters ). Jadi, sejak lahir anak itu tidak mempunyai bakat dan pembawaan apa-apa. Anak dapat di bentuk sekehendak pendidiknya. Disini kekuatan ada pada pendidik. Pendidikan dan lingkungan berkuasa atas pembentukan anak. (Jhon Locke dalam Sardiman, 2003:97-98)

Pendapat Jhon Locke seperti di atas dapat disebut juga empirisme, yaitu suatu aliran atau paham yang berpendapat bahwa segala kecakapan dan pengetahuan manusia itu timbul dari pengalaman (empiris) yang masuk melalui alat indera.Kaum behavioris juga berpendapat 
senada dengan teori tabularasa itu. Behaviorisme tidak mengakui adanya pembawaan dan keturunan, atau sifat-sifat yang turun temurun.Semua pendidikan, menurut behaviorisme, adalah pembentukan kebiasaan, yaitu menurut kebiasaan-kebiasaan yang berlaku di dalam lingkungan seorang anak.

\section{b. Teori Nativisme (Schopenhauer)}

Lawan dari empiris ialah nativisme. Nativus (latin) berarti karna kelahiran. Aliran navitisme berpendapat bahwa tiap-tiap anak sudah mempunyai berbagai pembawaan yang akan berkembang sendiri menurut arahnya masing-masing. Pembawaan anak-anak itu ada baik dan ada yang buruk.Pendidikan tidak perlu dan tidak berkuasa apa-apa. (Arthur Schopenhaur 1950:89). Kedua teori tersebut ternyata berat sebelah. Kedua teori tersebut ada benarnya dan ada pula tidak benarnya. Maka dari itu, untuk mengambil kebenaran dari keduanya, William Stren, ahli ilmu jiwa bangsa Germany, telah memadukan kedua teori itu menjadi satu teori yang disebut teori konvergensi.

\section{c. Teori Konvergensi (William Stren)}

Menurut teori konveregensi hasil pendidikan anak di pengaruhi oleh dua faktor, yaitu pembawaan dan lingkungan.Diakui bahwa anak lahir telah memiliki potensi berupa pembawaan. Betapa besarnya kecintaan tiap-tiap orang tua kepada anaknya memang sukar untuk mencari tolok bandingnya. Segala sesuatu yang mereka lakukan baik yang sesuai maupun yang tidak sesuai sama sekali dengan alam dan jaman adalah semata-mata demi kepentingan seorang anak. Kurangnya perhatian orang tua terhadap anaknya yang sedang senang mengadakan eksperimen, juga akan memupuk sifat negatif yang cenderung menjauhi arah perkembangan ideal yang diharapkan.

\section{METODE PENELITIAN}

Jenis penelitian yang digunakan dalam penelitian ini adalah penelitian kuantitatif dengan menggunakan metode korelasi di mana metode korelasi merupakan suatu penelitian untuk menggambarkan dua atau lebih fakta-fakta dan sifat-sifat objek yang di teliti. Jika dilihat dari objek yang diteliti, penelitian ini mengkaji tentang Pengaruh Latar Belakang Pendidikan Orang Tua Terhadap pola asuh Anak Pada Masyarakat Liukang Kalmas Kabupaten Pangkep. Penelitian ini akan dilaksanakan selama kurang lebih 1 tahun yakni bulan Mei 2017 sampai dengan bulan Mei 2018 di Liukang Kalmas Kabupaten Pangkep. 
Hal-hal yang menjadi Sasaran penelitian dalam penelitian ini adalah masyarakat Liukang Kalmas Kabupaten Pangkep.Dalam penelitian teknik pengambilan informan yang digunakan peneliti adalah purposive sampling yaitu dengan memilih secara langsung informan berdasarkan kriteria yang telah ditentukan peneliti. Jumlah informan dalam penelitian 138 orang. Adapun yang menjadi informan kunci adalah : orang tua dari yang tamatan SLTP,SMA, dan S1. Jenis data dalam penelitian ini yakni Data primer (langsung terhadap objek) dan data sekunder (diperoleh melalui media). Adapun teknik pengumpulan data yang dilakukan dalam penelitian ini adalah: observasi, dokumentasi, partisipatif, dan angket. Untuk memperoleh hasil penelitian yang lengkap, tepat dan benar, maka diperlukan metode yang valid dalam menganalisa data.

\section{HASIL DAN PEMBAHASAN}

Setelah melakukan observasi, dokumentasi, partisipatif,dan angket di lapangan maka akan disajikan data-data yang diperoleh dari penelitian. Untuk lebih jelasnya dapat dilihat sebagai berikut :

\section{Pengaruh Tingkat Pendidikan Orang Tua Terhadap Pola Asuh Anak}

Hasil penelitian ini memaparkan penelitian yang telah dilakukan yang meliputi tahap persiapan penelitian, pelaksanaan penelitian dan pembahasan sebagai berikut, hal pertama adalah menetapkan obyek penelitian pada Orang tua yang berada pada masyarakat Liukang Kalmas Kabupaten Pangkep.

\section{a. Pola Asuh Anak}

Dari kuisionare yang di ujikan mengenai pola asuh mendapatkan jawaban dibawah ini; Tabel 5.1 Hasil Uji Coba Pola Asuh anak

\begin{tabular}{|l|l|l|l|}
\hline No & \multicolumn{1}{|c|}{ Kriteria } & \multicolumn{1}{|c|}{$\begin{array}{c}\text { Jumlah Jawaban } \\
\text { Responden }\end{array}$} & \multicolumn{1}{|c|}{ Persentase } \\
\hline 1 & Sangat baik & 3 & $10 \%$ \\
\hline 2 & Baik & 14 & $47 \%$ \\
\hline 3 & Cukup & 12 & $40 \%$ \\
\hline 4 & Tidak baik & 1 & $3 \%$ \\
\hline 5 & Sangat tidak baik & 0 & $0 \%$ \\
\hline Jumlah & 30 & $100 \%$ \\
\hline
\end{tabular}

\section{b. Pendidikan Orang tua}

Dari kuisionare yang di ujikan mengenai pola asuh mendapatkan jawaban dibawah ini; Tabel 5.2 Hasil Uji Coba Pendidikan Orang tua 


\begin{tabular}{|l|l|l|l|}
\hline No & \multicolumn{1}{|c|}{ Kriteria } & \multicolumn{1}{|c|}{$\begin{array}{c}\text { Jumlah Jawaban } \\
\text { Responden }\end{array}$} & \multicolumn{1}{|c|}{ Presentase } \\
\hline 1 & Sangat baik & 2 & $7 \%$ \\
\hline 2 & Baik & 16 & $53 \%$ \\
\hline 3 & Cukup & 11 & $37 \%$ \\
\hline 4 & Tidak baik & 1 & $3 \%$ \\
\hline 5 & Sangat tidak baik & 0 & $0 \%$ \\
\hline Jumlah & 30 & $100 \%$ \\
\hline
\end{tabular}

\section{c. Hasil Sebaran Data kuisionare Pendidikan orang tua.}

Selanjutnya hasil dari sebaran data kuisionare di bedakan menjadi 3, yaitu sebagai berikut;

\section{Berpendidikan Sarjana}

Berpendidikan sarjana dengan hasil jumlah koresponden sejumlah 25 orang yang berpendidikan sarjana dari kuisionare yang diujikan mengenai pola asuh mendapatkan jawaban dibawah ini;

Tabel 5.3 Hasil sebaran Orang Tua Pendidikan Sarjana

\begin{tabular}{|l|l|l|l|}
\hline No & \multicolumn{1}{|c|}{ Kriteria } & \multicolumn{1}{|c|}{$\begin{array}{c}\text { Jumlah Jawaban } \\
\text { Responden }\end{array}$} & \multicolumn{1}{|c|}{ Persentase } \\
\hline 1 & Sangat baik & 2 & $8 \%$ \\
\hline 2 & Baik & 12 & $48 \%$ \\
\hline 3 & Cukup & 9 & $36 \%$ \\
\hline 4 & Tidak baik & 2 & $8 \%$ \\
\hline 5 & Sangat tidak baik & 0 & $0 \%$ \\
\hline & Jumlah & 25 & $100 \%$ \\
\hline
\end{tabular}

\section{Berpendidikan SLTA/SMA}

Dari kuisionare yang di ujikan mengenai pendidikan orang tua pada orang tua berpendidikan SLTA dengan jumlah responden 61 orang mendapatkan jawaban dibawah ini :

Tabel 5.4 Hasil sebaran Orang Tua Pendidikan SLTA/SMA

\begin{tabular}{|l|l|l|l|}
\hline No & \multicolumn{1}{|c|}{ Kriteria } & Jumlah Jawaban Responden & \multicolumn{1}{c|}{ Presentase } \\
\hline 1 & Sangat baik & 2 & $3 \%$ \\
\hline 2 & Baik & 45 & $74 \%$ \\
\hline 3 & Cukup & 12 & $20 \%$ \\
\hline
\end{tabular}




\begin{tabular}{|l|l|l|l|}
\hline 4 & Tidak baik & 2 & $3 \%$ \\
\hline 5 & Sangat tidak baik & 0 & $0 \%$ \\
\hline \multicolumn{2}{|c|}{ Jumlah } & 61 & $100 \%$ \\
\hline
\end{tabular}

\section{Berpendidikan SLTP/SMP}

Dari kuisionare yang diujikan mengenai pendidikan orang tua pada orang tua berpendidikan SLTP dengan jumlah responden 52 orang mendapatkan jawaban dibawah ini;

Tabel 5.5 Hasil sebaran Orang Tua Pendidikan SLTP/SMP

\begin{tabular}{|l|l|l|l|}
\hline No & \multicolumn{1}{|c|}{ Kriteria } & \multicolumn{1}{|c|}{$\begin{array}{c}\text { Jumlah Jawaban } \\
\text { Responden }\end{array}$} & \multicolumn{1}{|c|}{ Presentase } \\
\hline 1 & Sangat baik & 0 & $0 \%$ \\
\hline 2 & Baik & 18 & $34.61 \%$ \\
\hline 3 & Cukup & 29 & $56 \%$ \\
\hline 4 & Tidak baik & 5 & $9.39 \%$ \\
\hline 5 & Sangat tidak baik & 0 & $0 \%$ \\
\hline Jumlah & 52 & $100 \%$ \\
\hline
\end{tabular}

\section{Gabungan Tingkat Pendidikan Orang Tua Variabel (X)}

Dari kuisionare yang di ujikan mengenai pendidikan orang tua pada dengan jumlah responden 138 orang mendapatkan jawaban dibawah ini;

Tabel 5.6 Hasil sebaran Gabungan Tingkat Pendidikan Orang Tua

\begin{tabular}{|l|l|l|l|}
\hline No & \multicolumn{1}{|c|}{ Kriteria } & \multicolumn{1}{|c|}{$\begin{array}{c}\text { Jumlah Jawaban } \\
\text { Responden }\end{array}$} & \multicolumn{1}{|c|}{ Presentase } \\
\hline 1 & Sangat baik & 4 & $2.89 \%$ \\
\hline 2 & Baik & 80 & $57.97 \%$ \\
\hline 3 & Cukup & 45 & $33 \%$ \\
\hline 4 & Tidak baik & 9 & $7 \%$ \\
\hline 5 & Sangat tidak baik & 0 & $0 \%$ \\
\hline Jumlah & 138 & $100 \%$ \\
\hline
\end{tabular}

\section{Hasil sebaran data Pola Asuh}

Dari kuisionare yang di ujikan mengenai pendidikan orang tua pada dengan jumlah responden 138 orang mendapatkan jawaban dibawah ini :

Tabel 5.7 Hasil sebaran Data Pola Asuh

\begin{tabular}{|l|l|l|l|}
\hline No & \multicolumn{1}{|c|}{ Kriteria } & \multicolumn{1}{|c|}{$\begin{array}{c}\text { Jumlah Jawaban } \\
\text { Responden }\end{array}$} & Persentase \\
\hline 1 & Sangat baik & 13 & $9.42 \%$ \\
\hline
\end{tabular}




\begin{tabular}{|l|l|l|l|}
\hline 2 & Baik & 122 & $88.40 \%$ \\
\hline 3 & Cukup & 3 & $2 \%$ \\
\hline 4 & Tidak baik & 0 & $0 \%$ \\
\hline 5 & Sangat tidak baik & 0 & $0 \%$ \\
\hline Jumlah & 138 & $100 \%$ \\
\hline
\end{tabular}

\section{A. Analisis Deskriptif}

Hasil analisis statistik deskriptif variabel pola Asuh (Y), Tingkat Pendidikan Orang Tua (X) dapat terlihat pada tabel 5.8 sebagai berikut;

Tabel 5.8 Hasil Analisis Statistik Deskriptif Variabel Penelitian

Descriptive Statistik

\begin{tabular}{|l|c|c|c|c|c|}
\hline & N & Minimum & Maximum & Mean & Std.Deviation \\
\hline $\begin{array}{l}\text { X Pend } \\
\text { Ortu }\end{array}$ & 138 & 57.00 & 88.00 & 73.9058 & 7.32846 \\
Y Pola Asuh & 138 & 66.00 & 97.00 & 80.8043 & 6.55895 \\
Valid N & 138 & & & & \\
(listwise) & & & & & \\
\hline
\end{tabular}

Berdasarkan Tabel 5.8 di atas dapat dijelaskan bahwa variabel Pola Asuh diperoleh mean sebesar 80.80 dengan standar deviasi sebesar 6.55895. Variabel Tingkat Pendidikan Orang Tua diperoleh mean sebesar 73.90 dengan standar deviasi sebesar 7.32846 Secara rinci dengan distribusi frekuensi deskripsi masing-masing variabel dijelaskan sebagai berikut:

\section{Deskripsi Variabel Pola Asuh}

Variabel Pola Asuh butir instrumen penelitian sebanyak 20 butir pertanyaan dengan 5 pilihan, selanjutnya untuk mengukur validitas dan reliabilitas instrumen yang akan digunakan dalam penelitian ini, akan penulis jabarkan satu persatu :

(1) Uji validitas

Dari hasil uji coba tersebut menghasilkan semua pertanyaan yang ada diangket baik dan benar sesuai dengan kriteria pengumpulan data melalui angket,baik angket Tingkat Pendidikan orang tua maupun Pola Asuh. 
2. Deskripsi Variabel Tingkat Pendidikan Orang Tua (X).

Variabel tingkat pendidikan orang tua dibutir instrument penelitian sebanyak 20 butir pertanyaan dengan 5 pilihan.

Tabel 5.10 Tingkat Pendidikan Orang Tua

\begin{tabular}{|c|c|c|c|c|}
\hline NO & Interval & Kriteria & Frekuensi & Persentase \\
\hline & $100-84$ & Sangat Baik & 4 & $2.89 \%$ \\
\hline \multicolumn{5}{|l|}{1} \\
\hline & $83-68$ & Baik & 80 & $57.97 \%$ \\
\hline \multicolumn{5}{|l|}{2} \\
\hline & $63-47$ & Cukup Baik & 45 & $33 \%$ \\
\hline \multicolumn{5}{|l|}{3} \\
\hline & $46-30$ & KurangBaik & 9 & $7 \%$ \\
\hline \multicolumn{5}{|l|}{4} \\
\hline & $29-15$ & Tidak Baik & 0 & $0 \%$ \\
\hline \multicolumn{5}{|l|}{5} \\
\hline \multirow{2}{*}{\multicolumn{2}{|c|}{ Jumlah }} & & 138 & $100 \%$ \\
\hline & & & & \\
\hline
\end{tabular}

\section{B. Hasil Uji Hipotesis Pengaruh Tingkat Pendidikan orang tua(X) Terhadap Pola Asuh (Y)}

Berdasarkan output koefisien korelasi, diperoleh koefisien korelasi sebesar 0.349 dan koefisien ini bertanda positif. Model hubungan Tingkat Pendidikan orang tuadengan Pola Asuh adalah signifikan, hal ini ditunjukan oleh besarnya nilai uji $t=3.384$ lebih besar jika dibanding dengan t tabel alpha $0.05(\mathrm{df}=138)$ sebesar 1.063 .

Tabel 5.11 Coefficients Pendidikan Orang Tua terhadap Pola Asuh

Coefficients $^{\mathrm{a}}$

\begin{tabular}{|c|c|c|c|c|c|}
\hline \multirow[t]{2}{*}{ Model } & \multicolumn{2}{|c|}{$\begin{array}{l}\text { Unstandardized } \\
\text { Coefficients }\end{array}$} & $\begin{array}{l}\text { Standardize } \\
\qquad d \\
\text { Coefficients }\end{array}$ & $T$ & Sig. \\
\hline & B & Std. Error & Beta & & \\
\hline 1 (Constant) & $\begin{array}{l}45.711 \\
.349\end{array}$ & 7.379 & & 6.195 & .000 \\
\hline POLA ASUH & & & .312 & & \\
\hline
\end{tabular}




\begin{tabular}{|l|l|l|l|l|l|}
\hline & & .091 & & 3.834 & .000 \\
\hline
\end{tabular}

a. Dependent Variable: Pendidikan Orang Tua

Berdasarkan output di atas diperoleh koefisien regresi sebesar 0.349 dan konstanta sebesar 45.711. Maka dapat digambarkan bentuk hubungan variabel Tingkat Pendidikan orang tuadan Pola Asuh dalam bentukpersamaan regresi $Y=45.711+0.349 \mathrm{X}$. Ini berarti bahwa jika Tingkat Pendidikan orang tua meningkat 1 poin maka Pola Asuh akan meningkat sebesar 0.349 poin pada konstanta 45.711 .. Dengan kata lain bahwa semakin baik Tingkat Pendidikan orang tua maka Pola Asuh akan meningkat. Berdasarkan output komputer tersebut dapat dijelaskan bahwa diperoleh nilai R square sebesar 0.198. Hal ini berarti bahwa variable Tingkat Pendidikan orang tua berpengaruh terhadap Pola Asuh sebesar $19.8 \%$, dan sisanya sebesar $79.2 \%$ ditentukan oleh sebab lain di luar model tersebut.

\section{Hasil Penelitian Pengaruh Tingkat Pendidikan Orang Tua (X) Terhadap Pola Asuh (Y)}

Hasil analisis deskripsi menunjukan bahwa Pola Asuh dalam menjalankan tugasnya dengan kategori sangat baik yaitu sebesar $34.03 \%$ yaitu diperoleh mean 64.7639 yang terletak pada interval 385-323, kategori baik yaitu sebesar 63.19\% yang terletak pada interval 322260. Dan cukup baik $2.77 \%$ pada interval 259-197. Tingkat Pendidikan orang tua dalam kategori sangat baik sebesar $9.12 \%$, baik sebesar $86.80 \%$ dan cukup baik sebesar $4.16 \%$.

Tingkat Pendidikan orang tua terhadap Pola Asuh, yaitu sebesar $19.1 \%$ seperti pada Model Summary di bawah ini

\section{KESIMPULAN}

Ada pengaruh positif dan signifikan Tingkat Pendidikan orang tua terhadap Pola Asuh sebesar $19,1 \%$, pengaruh positif itu jika Tingkat Pendidikan orang tua semakin baik maka Pola Asuh semakin baik, Tingkat Pendidikan orang tua dan Pola Asuh semakin baik maka Pola Asuh semakin baik. Sedangkan faktor-faktor lain yang mendukung meningkatnya Pola Asuh sebesar $80.9 \%$ diantaranya lingkungan, sosial budaya, supervise serta lainya terkait peningkatan Pola Asuh. Selanjutnya bahwa dilihat dari hal pendidikan dari SMP hingga sarjana bisa di simpulkan sebagai berikut; 
1) Untuk orang tua berpendidikan SMP persentase sangat baik berjumlah $8 \%$, Baik $48 \%$ orang, Cukup Baik 36\% orang dan Tidak Baik berjumlah $8 \%$ orang. Yang sangat tidak baik $0 \%$.

2) Untuk orang tua berpendidikan SMA persentase sangat baik berjumlah $3 \%$, Baik $74 \%$ orang, Cukup Baik 20\% orang dan Tidak Baik berjumlah 3\% orang. Yang sangat tidak baik $0 \%$.

3) Untuk orang tua berpendidikan Sarjana persentase sangat baik berjumlah $0 \%$, Baik $34.61 \%$ orang, Cukup Baik 56\% orang dan Tidak Baik berjumlah 10\% orang. Yang sangat tidak baik $0 \%$.

\section{DAFTAR PUSTAKA}

Asdiar.(2014). Pandangan Keluarga Pemulung terhadap Pendidikan Formal. Skripsi tidak diterbitkan. Makassar. Unismuh Makassar.

Bugis Fatma. 2015. Pendidikan Gratis dan Perilaku Sosial Keluarga Miskin. Skripsi tidak diterbitkan.Makassar. Unismuh Makassar.

Bahri Saiful. 2004. Pola Komunikasi Orang Tua dan Anak Dalam keluarga.Jakarta : Rineka Cipta.

Depdikbud.(1993). Kamus Besar Bahasa Indonesia.Jakarta : Balai Pustaka.

Din Wahyudin, 2007, Pengantar Pendidikan, Jakarta.

Hasbullah. 2011. Dasar-dasar IImu Pendidikan. Jakarta : Rajawali Pers.

http://www.beritaterhangat.net/2012/08/definisi-dan-pengertian-pendidikan.html

Kamrin. 2014. Pandangan Masyarakat Terhadap Pendidikan Tinggi. Skripsi tidak diterbitkan. Makassar. Unismuh Makassar.

Lita Latiana, Buku Ajar 2003. Pendidikan Anak dalam keluarga.

Rosalia Tukan. (2015). Peranan Keluarga dalam Pendidikan Anak Remaja Berbasis Islam. Skripsi tidak diterbitkan. Makassar. Unismuh Makassar.

Rusmala 2010. "Korelasi Tingkat Pendidikan Orang Tua Terhadap Prestasi Belajar Siswa SMA Negeri 1 Bulupoddo Kecamatan Bulupoddo Kabupaten Sinjai

Rohman, Arif. 2009. Memahami Pendidikan dan Ilmu Pendidikan. Mediatama : Yogyakarta.

Soekanto, Soerjono 2004.Sosiologi Keluarga : tentang ikhwal keluarga, remaja dan anak. Jakarta : PT. Rineka Cipta.

Sadulloh Uyoh. 2015. Pedagogik (Ilmu mendidik). Bandung : Alfabeta

Soekanto Soerjono. 2012. Sosiologi Suatu Pengantar. Jakarta : PT. Raja grafindo Persada.

Sugiyono. 2011. Metode Penelitian Kuantitatif Kualitatif dan R\&D. Bandung: Alfabeta. 